Printed in Great Britain

\title{
ODOSTOMIA AS A PEST OF OYSTERS AND MUSSELS
}

\author{
By H. A. Cole and D. A. Hancock \\ Fisheries Laboratory, Burnham-on-Crouch, Essex
}

(Plates I and II and Text-fig. I)

A recent study by Fretter \& Graham (I949) has shown that members of the family Pyramidellidae are ectoparasites, each species feeding on a particular host, usually a tubicolous polychaete or a lamellibranch, by piercing the body wall with the buccal stylet and sucking blood, and perhaps tissue debris, by means of the buccal pump. A list of hosts, each with its specific parasite, was given.

Subsequently, Cole (I95I) recorded the presence in oysters of a species, Odostomia eulimoides Hanley, which had been observed by Fretter \& Graham, and recorded previously by Jeffreys (1867), as feeding on Pecten maximus (Linné) and Chlamys opercularis (Linné). The Odostomia were lodged in small pockets inside the ventral margin of the shell of 2-year-old native brood oysters dredged from near Paglesham in the River Roach, Essex. The pockets were formed as a consequence of the withdrawal of the mantle in response to the irritation caused by the proboscis of the parasite during feeding.

It was suggested that, although Odostomia could not be regarded as a major parasite of oysters, its attack must result in considerable irritation, some loss of condition, and possibly small permanent malformations of the shell.

In December I953, Mr J. E. Francis, foreman of the Colne Fishery Board, brought to the Burnham Laboratory some oysters of marketable size, i.e. 5-6 years of age, taken from the Pyefleet Channel, River Colne, which appeared to be suffering from the cumulative effects of attacks by Odostomia. Many of the oysters were malformed and some were dying. Oysters in a similar condition had been noted about 7 years previously. Further researches into the incidence of the parasite and its effects on oysters form the basis of this paper.

We are much indebted to the Colne Fishery Board, and in particular to Mr Francis, for material and information. We are also indebted to Dr Vera Fretter for the identification of the species of Odostomia found during the investigations. 


\section{OBSERVATIONS}

Odostomia in Oysters

A sample of forty oysters was received from the Pyefleet Channel in January I954. They had been noticed and removed by oystermen during normal dredging operations from among several thousand oysters of marketable size. They were 5-6 years of age, and $76 \mathrm{~mm}$ in average diameter. These oysters were specially selected as having some malformation of the edge of the shell, and it was estimated by Mr Francis that they occurred once or twice in every 2000 oysters. Of the forty oysters received, all showed symptoms similar to, but far more serious than, those recorded by Cole (I95I) as resulting from an attack by $O$. eulimoides. The presence of a small gastropod was noted, and this was found to be the same species of Odostomia. In one dying oyster no less than seven Odostomia were found. In others one, two or three were present. In some no parasites were found, but, since the oysters had been collected several days before and kept alive in baskets in the oyster pits, and had been handled frequently during dredging and sorting, it is not surprising that they had been lost.

In less severe cases the Odostomia were observed in small characteristic pockets usually on the ventral or anterior margin of the oyster (Pl. I, fig. I). These were similar to those described by Cole (I95I). Prolonged irritation by a larger number of Odostomia, however, causes a much more violent response by the oyster. The pockets become merged to affect almost the whole edge of the shell, and penetrate farther towards the adductor muscle. The edges of the pocket are marked by numerous thin, approximately parallel, laminae of shell substance, marking the successive positions of the withdrawn mantle edge as the oyster had attempted to evade the probing of the parasite. The margin of the shell becomes thickened, in the worst cases being approximately I $\mathrm{cm}$ wide with double or triple lips (Pl. I, fig. 2).

In the most severe cases, the constant irritation appears to interfere with the normal metabolism of the oyster. Great ridges of shell substance are laid down following the path of the withdrawn mantle. Finally the point of attachment of the adductor muscle is reached, but the process continues, with the result that the adductor muscle is almost completely covered by a thorn-like ridge of brownish deposited shell material (Pl. I, fig. 3). Attack from the ventral margin, as normally occurs, will first affect the catch component of the adductor muscle and will cause the oyster to gape. In this condition, sand and silt will be driven into the mantle cavity with resultant suffocation and death. Such a condition was, in fact, commonly observed among the severely affected oysters. In one severe instance, only a narrow band of one-tenth of the adductor muscle remained fully functional. This displacement of the adductor muscle may occur inside either valve of the oyster (Pl. I, fig. 3; Pl. II, fig. 4), 
but is most usually found in the flat valve. Sometimes, the two valves are affected simultaneously, resulting in a condition in which it is virtually impossible for the oyster to close. In most of the severe cases it was possible to follow the development of the attack by the presence of successive layers and ridges of shell which led back to the damaged adductor muscle. Occasionally, however, although the margin of the oyster shell showed severe pockets, a thorn-like growth was present intruding into the adductor muscle with no connecting layers of similar material between it and the pockets (P1. II, fig. 5). The impression received was one of severe irritation of the oyster, with consequent strain on the adductor muscle, which had manifested itself in a violent disturbance of its metabolism.

In several of the oysters examined, retraction of the mantle, accompanied by thickening of the edges of the shell, had taken place to such an extent that there had been room for settlement of mussel spat inside the margins of the two valves. The mussels had grown, causing the valves to part even more, finally producing the effect shown in P1. II, fig. 6.

Of the forty oysters examined in this sample, twenty were so severely affected that the adductor muscle was damaged, and of these, eleven were dying or already dead from the effects of Odostomia. It should be mentioned that none of these oysters showed evidence of shell disease, which occurs very rarely in the River Colne, but which when present produces in its final stages effects of a somewhat similar nature in oysters. Occasionally severe attack by Polydora may produce blisters on the shell which resemble the pockets caused by light attack by Odostomia. With practice, a substantial proportion of oysters affected by Odostomia may be detected in the field by the thickening and distortion of the shell edge. However, the superficial resemblance between the condition it causes, in the early stages of attack, and damage by other enemies, such as Polydora, has delayed the recognition of the parasite on beds where it is now known to occur.

The appearance of such badly affected oysters on the Colne Fishery amongst those intended for market caused some concern. It was decided to investigate the frequency of the occurrence of Odostomia in younger oysters on the grounds in the River Colne from which oysters intended for market are taken for final fattening in the Pyefleet Channel. A random sample of 3-year-old brood oysters was dredged, isolated carefully, and examined for the presence of Odostomia. In ten, of fifty-four oysters, Odostomia was actually present, each of the oysters showing retraction of the mantle and typical pocketing of the shell margin. In six others there was definite evidence, and in four slight evidence, that Odostomia had been present. A maximum of three Odostomia was found in one oyster, and a total of fifteen in the ten oysters. Three additional Odostomia were found in the container. This represents a minimum of $30 \%$ incidence of $O$. eulimoides in 3-year-old brood oysters at the lower end of the oyster grounds in the River Colne. Samples from higher upstream 
indicate that Odostomia occurs less abundantly there, but the full pattern of its distribution has not yet been determined.

The evidence that Odostomia attack can cause the death of some oysters, and may render others unfit for consumption, led to a search for the parasite when examining oysters from other areas. A feature of its occurrence is its appearance in unexpected circumstances, which has led to the belief that the general incidence of Odostomia in oysters must be high. For example, the first oyster opened in the River Colne for a condition measurement contained an Odostomia. A small brood oyster from Creeksea, River Crouch, examined for drilling by Urosalpinx, contained Odostomia. The first oysters opened at Fambridge, River Crouch, and in Salcombe harbour, for other reasons, each contained Odostomia. In the River Crouch, $17 \%$ of the brood oysters from Brickfield Bight, Bridgemarsh Island, a ground approximately mid-way between the head-waters and the mouth, were infected, while $8 \%$ of the brood oysters taken from the Shop Laying, Paglesham, River Roach, also contained Odostomia.

O. eulimoides has now been recorded in oysters from Creeksea, Brickfield Bight and Fambridge in the River Crouch, and Shop Laying and Common Shore in the River Roach. An oyster from Salcombe harbour contained a pyramidellid which proved to be a different species, Chrysallida obtusa (Brown) which is here recorded for the first time in oysters.

\section{Odostomia in Mussels}

Information had been received from Dr E. W. Knight-Jones that Odostomia scalaris (Macgillivray) was present in large numbers on Mytilus edulis (Linné) from the pontoon of Menai Bridge pier. It was thought that an investigation of these mussels might provide a useful comparison with the effects of Odostomia on oysters. A sample of 200 mussels, kindly despatched by rail by Dr Knight-Jones, was examined for the presence of Odostomia and for any retraction of the mantle comparable with the condition found in oysters. Retraction of the mantle to form a pocket had occurred in eight of the mussels, and, although the Odostomia were not present inside the shell, there is little doubt that they had been the cause. The pockets were strictly similar in form to those described in oysters (see Text-fig. I). Each occurred usually on one valve, while the other valve had overgrown slightly in an effort to complete the gap. The pocket was then just visible externally as a slight twist in the shell margin. Forty-two $O$. scalaris were found on the outer surfaces of the mussels and in the container. Several of these were kept alive in an aquarium tank with small Mytilus, and after a short time were found to have taken up a feeding position. Each Odostomia was attached to the outer edge of one of the valves with its proboscis protruding into the siphonal aperture of the mussel, and they remained in this position for several days. The length of the proboscis was such that it could have produced the retrac- 
tion of the mantle without actual entry of the Odostomia between the valves as occurs in oysters. This, combined with the fact that the mussels had undergone a long rail journey, may explain why no Odostomia were found inside the shells of the mussels.
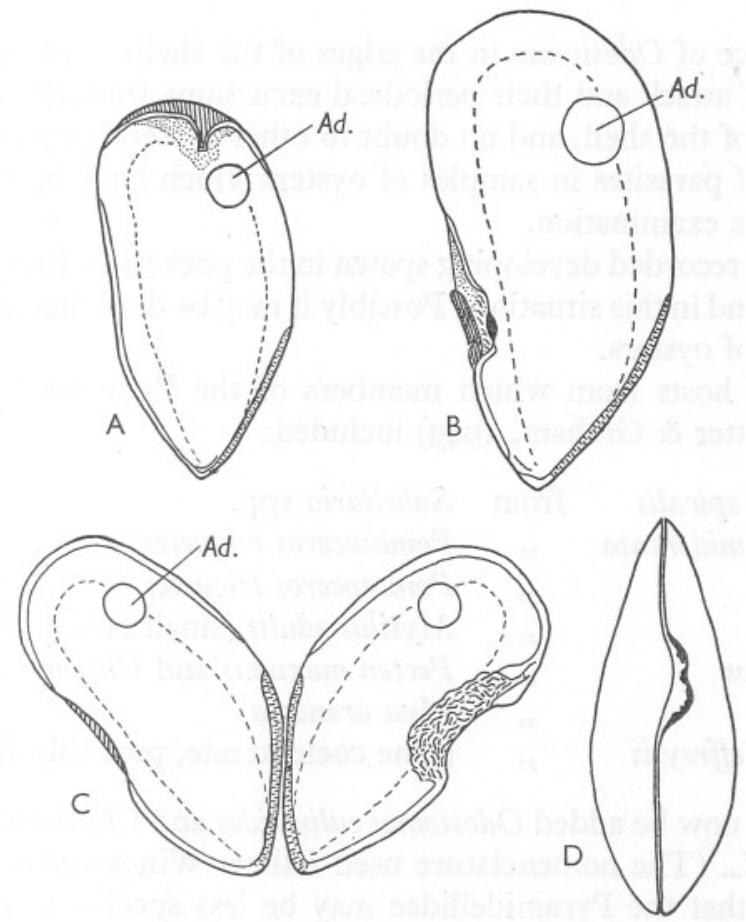

Text-fig. I. A, B, Inner surfaces of the left valves of two mussels showing 'pockets' caused by Odostomia; A, in posterior margin, B, in ventral margin. C, inner surface of mussel attacked by Odostomia at ventral margin. D, ventral margin of mussel C. Ad., adductor muscle.

\section{Discussion}

In the present investigation up to seven O.eulimoides were found in one oyster, but, since many parasites are lost during dredging and handling, it is likely that still more may occur in large oysters. Cole (I95I) found two pairs occupying separate pockets in small 2-year-old oysters from the River Roach, Essex, but the damage caused was not severe. It may be conjectured, therefore, that the very serious damage here described is either produced by substantially more than the maximum number so far recorded, or by attack by smaller numbers over a period of years.

It is probable that in the first stages of attack the Odostomia attach themselves to the lips of the shell and probe the edges of the mantle with their long probosces. Later, as a pocket is formed by the deposition of new shell along the line of the retracted mantle edge, near the site of attack, the Odostomia are able 
to move inside the shell and live more or less permanently within the oyster. It is clear, however, that they must leave the pockets at times, e.g. when copulation takes place, and in an aquarium tank Odostomia have been noticed moving over the outer surface of oysters which had obviously suffered from attack.

The presence of Odostomia in the edges of the shells of oysters during the early stages of attack and their periodical excursions from the pockets to the outer surface of the shell, and no doubt to other oysters, explains the relative infrequency of parasites in samples of oysters which have been dredged and handled before examination.

Cole (I95I) recorded developing spawn in the pockets in June, but none has since been found in this situation. Possibly it may be deposited also in crevices on the shells of oysters.

The list of hosts from which members of the Pyramidellidae had been recorded (Fretter \& Graham, 1949) included:

\begin{tabular}{|c|c|c|}
\hline Chrysallida spiralis & from & Sabellaria spp. \\
\hline Odostomia unidentata & & Pomatoceros triqueter \\
\hline O. lukisii & דק & Pomatoceros triqueter \\
\hline O. scalaris & & Mytilus edulis (small only) \\
\hline O. eulimoides & & Pecten maximus and Chlamys opercularis \\
\hline O. trifida & & Mya arenaria \\
\hline Turbonilla jeffreysii & & some coelenterate, probably Halecium s \\
\hline
\end{tabular}

To these may now be added Odostomia eulimoides and Chrysallida obtusa from Ostrea edulis L. (The nomenclature used follows Winckworth, I932.)

It appears that the Pyramidellidae may be less specific in their choice of host than has been suggested.

Odostomia, as a parasite of oysters, has some practical importance, not only because of its frequency in young oysters whose growth is likely to be retarded. It has been shown that full-grown oysters may be seriously weakened and killed and it would be inadvisable to include obviously infected oysters in a market consignment, since the discovery of a number in the condition illustrated might prejudice future sales. No measure of control can so far be suggested other than the destruction of large oysters which show the multiplelipped condition and are light in weight, suggesting low flesh content.

\section{SUMMARY}

A description is given of serious damage to oysters of marketable size taken from the River Colne, Essex, caused by Odostomia eulimoides. An incidence of $30 \%$ infection was found in 3-year-old oysters.

Chrysallida obtusa is recorded for the first time as a parasite of oysters.

The effects of Odostomia scalaris on Mytilus edulis are similar to those described in oysters resulting from attack by Odostomia eulimoides. 

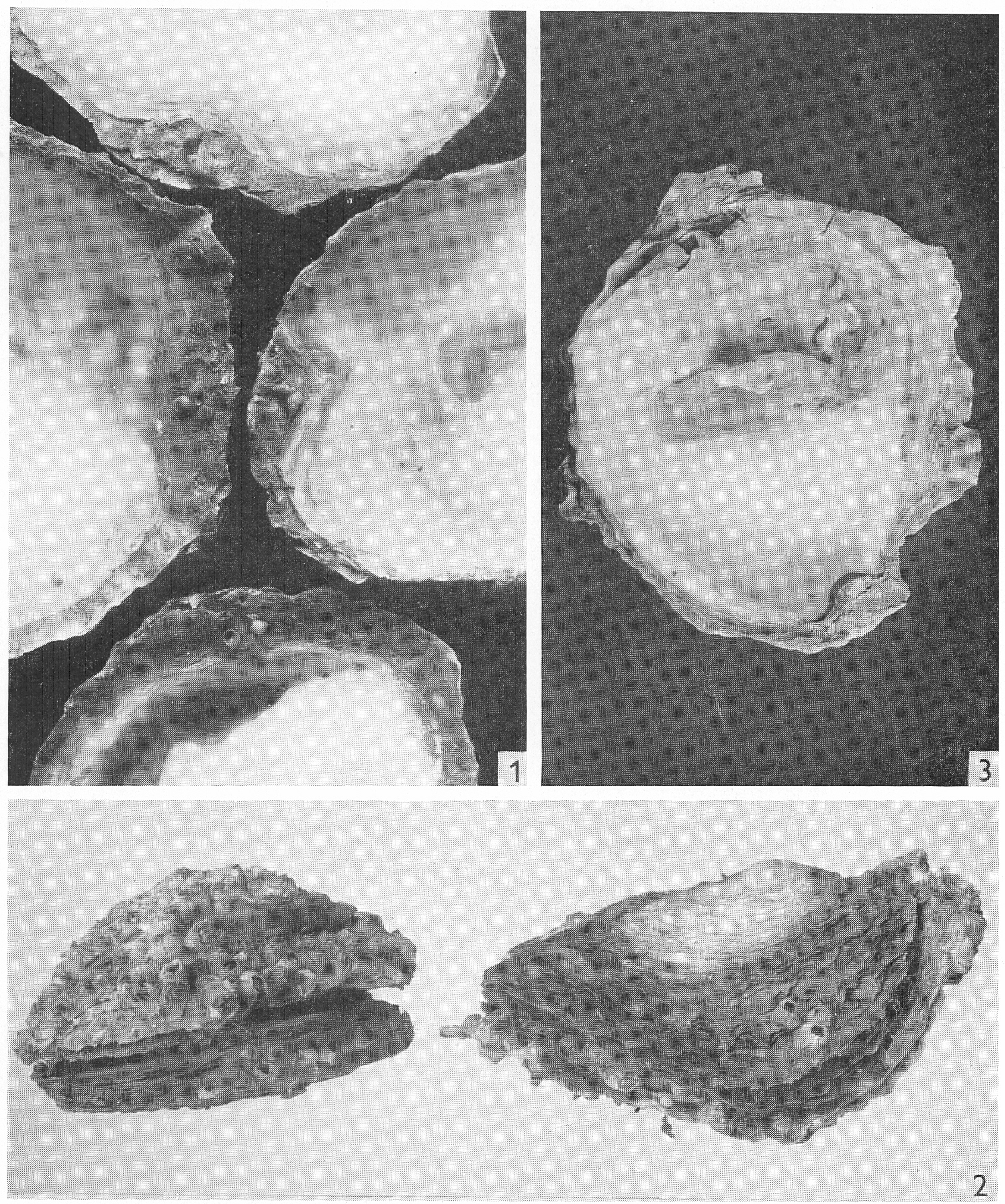

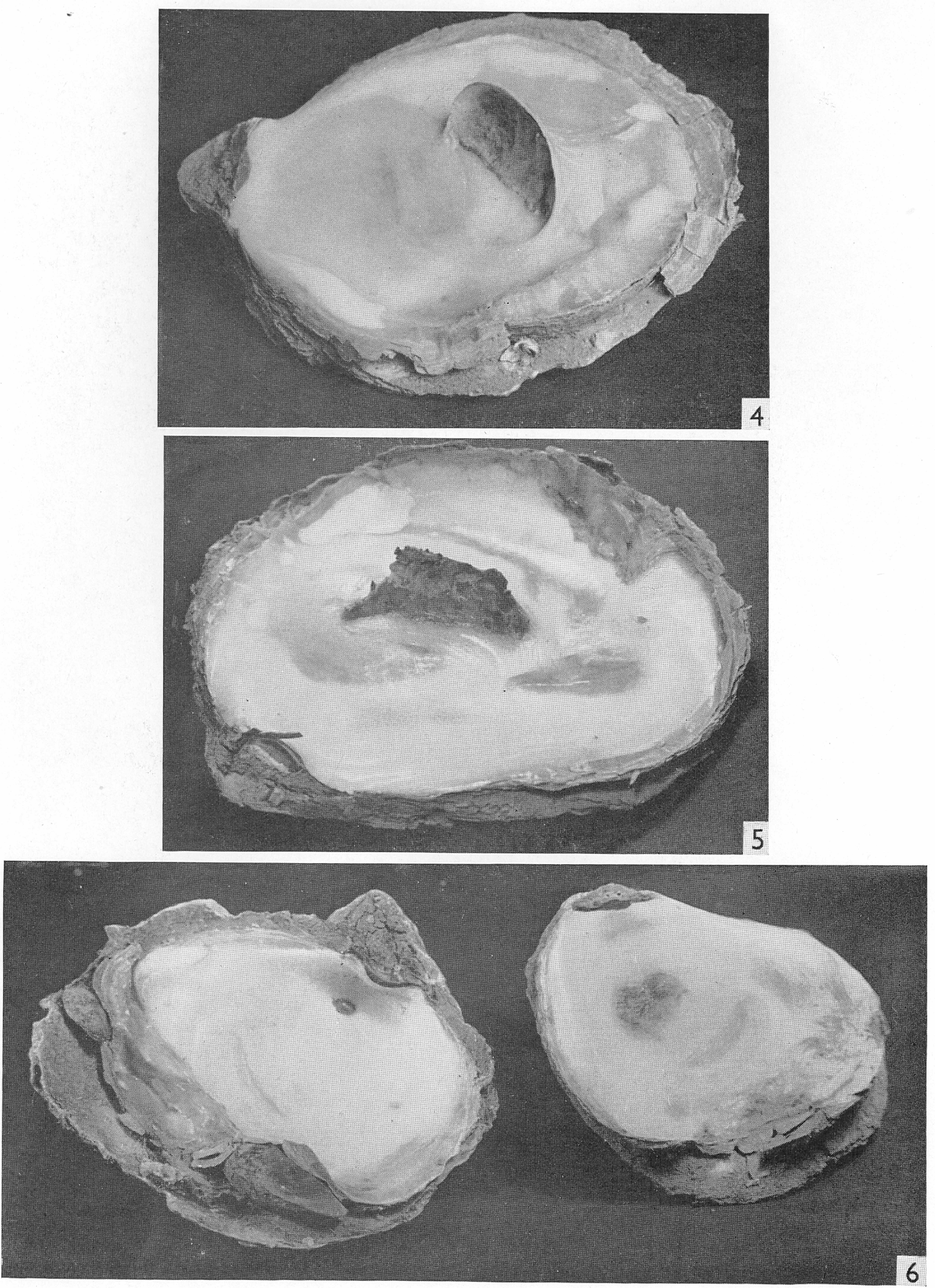


\section{REFERENCES}

Cole, H. A., I95I. An Odostomia attacking oysters. Nature, Lond., Vol. I68, pp. 953-4.

Fretter, V. \& Graham, A., I949. The structure and mode of life of the Pyramidellidae, parasitic opisthobranchs. F. Mar. biol. Ass. U.K., Vol. 28, pp. 493-532.

Jefrereys, J. G., I867. British Conchology, Vol. 4. London: John van Voorst.

WinckWorth, R., I932. The British marine Mollusca. f. Conch., Vol. I9, pp. 2 I I-52.

\section{EXPLANATION OF PLATES}

\section{Plate I}

Fig. I. Shells of Ostrea edulis showing Odostomia in situ in characteristic marginal 'pockets'. Fig. 2. Ventral margins of two oysters thickened as a result of Odostomia attack.

Fig. 3. Inner surface of the left valve of an oyster with adductor muscle attachment affected by severe attack by Odostomia.

Plate II

Fig. 4. Right valve of an oyster attacked by Odostomia.

Fig. 5. Right valve of an oyster showing typical Odostomia 'pocket' and affected adductor muscle attachment.

Fig. 6. Oyster shells showing effects of severe Odostomia attack and settlement of mussels between the valves. 